\title{
EVALUATION OF THE RESISTANCE OF TRANSGENIC C5 PLUM (Prunus domestica L.) AGAINST FOUR CHILEAN PLUM POX VIRUS ISOLATES THROUGH MICRO-GRAFTING
}

\author{
Wendy Wong ${ }^{1}$, Paola Barba ${ }^{2}$, Catalina Álvarez ${ }^{2}$, Álvaro Castro ${ }^{3}$, Manuel Acuña ${ }^{2}$, Pablo Zamora ${ }^{3}$, \\ Marlene Rosales², Paola Dell’Orto ${ }^{4}$, Michael R. Moynihan ${ }^{4}$, Ralph Scorza ${ }^{5}$, and Humberto Prieto ${ }^{2 *}$
}

\begin{abstract}
The transgenic plum (Prunus domestica L.) C5, in which the coat protein (CP) gene of the Plum pox virus (PPV) is inserted, represents a unique example of the use of genetic engineering for fruit crop improvement in Prunus spp. Field trials in Poland, Romania, and Spain have demonstrated resistance of C5 to several D and M strain PPV isolates. In Chile, the quarantine regulations for PPV and for genetically modified (GM) plants require that the testing of C5 for resistance to Chilean PPV isolates be done under controlled isolated conditions. To carry out these tests C5 shoots were multiplied in vitro and micro-grafted onto four Adesoto101 (Prunus insititia L.) rootstock populations that had been previously infected each with one of four Chilean PPV-Ds. Tests were carried out under controlled conditions in a biosafety greenhouse. Symptoms appearance, virus detection, and viral mRNA levels for the cylindrical inclusion (CI) and CP genes were determined during three consecutive growing seasons. Complete resistance to all PPV isolates was demonstrated during the first $2 \mathrm{yr}$ in all of the C5 plants. In the third season, four of 10 C5 plants showed mild symptoms on leaves close to the graft union and low but detectable CI mRNA levels in the C5 scions. These results support the effectiveness of using of micro-grafting on $P$. insititia for PPV resistance studies, especially in the limited space of a quarantine facility; whereas resistance levels in C5 after 3 yr indicate the importance of long term and field scale evaluations.
\end{abstract}

Key words: C5, Plum pox virus, Chilean isolates, Prunus domestica, Prunus insititia, micro-grafting.

\section{INTRODUCTION}

Few stone fruit or ornamental Prunus varieties highly resistant to Plum pox virus (PPV) have been generated by conventional breeding. Although some sources of resistance to PPV have been found within the genus Prunus (Karayiannis, 2006), obtaining resistant varieties by classic breeding is a long-term, labor and a land intensive process. Genetic transformation of Prunus domestica L. using a binary construct containing the coat protein $(\mathrm{CP})$ gene plus the 3' non-translated region

${ }^{1}$ Universidad de Chile, Facultad de Ciencias Agronómicas, PO Box 1004, Santiago, Chile.

${ }^{2}$ Instituto de Investigaciones Agropecuarias INIA, PO Box 549, Santiago, Chile. "Corresponding author (hprieto@inia.cl).

${ }^{3}$ Universidad de Santiago de Chile, Facultad de Química y Biología, PO Box 10233, Santiago, Chile.

${ }^{4}$ Fundación Chile, PO Box 6671199, Santiago, Chile.

${ }^{5}$ USDA Agricultural Research Service (ARS), Appalachian Fruit Research Station, Kearneysville, PO Box 45, West Virginia, USA.

Received: 17 June 2009.

Accepted: 11 November 2009. of the viral genome (EMBL Accession $\mathrm{N}^{\circ}$ X16415, Teycheney et al., 1989) resulted in the development of a PPV resistant variety HoneySweet, initially designated as C5 (Scorza et al., 1994). The high degree of resistance observed in this genetically modified variety has been stable in more than $10 \mathrm{yr}$ of evaluation in greenhouses and in the field (Hily et al., 2004; Malinowski et al., 2006; Polák et al., 2008). No C5 trees in any of these tests have become infected through natural aphid inoculation, and different grafting approaches have resulted in only a few instances of limited, mild disease symptoms (Polák et al., 2008; Kundu et al., 2008). The C5 event was granted deregulated status in June of 2007 by the USDA Animal and Plant Health Inspection Service and was cleared by the U.S. Food and Drug Agency in January 2009.

In Chile, PPV was first reported in 1992, and since then it has been considered as a quarantine disease. Despite of, it has spread to several commercial orchards of stone fruit trees in the central area of the country (Herrera and Madariaga, 2003). Molecular characterization and analysis of $\mathrm{CP}$ gene sequences of six different isolates 
have demonstrated the exclusive presence of the D strain of the virus, and the biological behavior has been studied in Prunus tomentosa Thunb. hosts in the greenhouse (Reyes et al., 2003).

Most of the evaluations of $\mathrm{C} 5$ trees have been carried out in European countries (Malinowski et al., 2006). Given the potential for severe impacts of PPV on the stone fruit industry in Chile, evaluation of the potential future use of C5 as a tool against Sharka disease in Chile is desirable, however, its quarantine status and the GM classification, make this task complex.

In this work it is described the first evaluation of the resistance provided by C5 against Chilean PPV isolates in a contained system for which the use of proper experimental procedures were adapted. Prunus insititia (Prunus domestica L. var. insititia (L.) Fiori \& Paoletti; Adesoto 101) is commercially used as a rootstock of plum (P. salicina Lindl.), peach (P. persica (L.) Batsch), apricot (P. armeniaca L.) and almond (P. dulcis (Mill.) D.A. Webb) trees; it presents adaptation to different types of soil, high productivity and it is resistant to nematodes (Moreno et al., 1995). This rootstock had already been reported as highly susceptible to PPV (Llácer and Cambra, 2006), but it had not been broadly used as a host in evaluations of the virus, probably due to the routine use of 'GF-305' and $P$. tomentosa. However and precisely because of their high sensitivity to PPV, these common indicators are becoming less used and out of stock in commercial nurseries. In order to evaluate C5 event against local PPV isolates under confined quarantine conditions, Adesoto 101 plants were used as both, host plants of four different PPV isolates previously characterized at molecular level and rootstock for micro-grafts of C5. Results of this experimental strategy allowed the evaluation of the C5 resistance against these Chilean PPV isolates by three consecutive spring-summer seasons.

\section{MATERIALS AND METHODS}

Plant material. Transgenic clone C5 was imported as dormant budwood in February 2004 and kept under quarantine and biosafety regulations as specified by the Servicio Agrícola y Ganadero, SAG (Chilean National Agriculture Service). Dormant budwood was induced to produce shoots by in vitro culturing of nodal segments of approximately $5 \mathrm{~cm}$ in length, on MS media (Murashige and Skoog, 1962) supplemented with $1 \mathrm{mg} \mathrm{L}^{-1}$ benzylaminopurine (BAP) and $0.25 \mathrm{mg} \mathrm{L}^{-1}$ indolebutyric acid (IBA). After 2 wk actively growing shoots were transferred to propagation medium (MS supplemented with IBA $0.1 \mathrm{mg} \mathrm{L}^{-1}$ and BAP $0.8 \mathrm{mg} \mathrm{L}^{-1}$ ). After $4 \mathrm{wk}$, in vitro shoots were $2-3 \mathrm{~cm}$ in height and were suitable for micro-grafting.
Prunus tomentosa plantlets (hybrid IR473 x IR474) were produced from certified virus free seeds from Washington State University, Prosser NRSP5 (National Research Support Project 5), USA. After removal of the endocarp seeds were stratified by mixing them with sterile perlite in a solution of benomyl (Benlate $0.5 \mathrm{mg} \mathrm{L}^{-1}$ ) captan $\left(1 \mathrm{mg} \mathrm{L}^{-1}\right)$ and then were stored at $4{ }^{\circ} \mathrm{C}$ for $2-3 \mathrm{mo}$. After roots started to emerge, seeds were potted in plastic containers with potting mix (soil:leaf-compost:sand as 50:20:10), placed in a greenhouse at $22-24{ }^{\circ} \mathrm{C}$ with $18: 6$ $\mathrm{h}$ light photoperiod, and watered with a $5 \mathrm{~g} \mathrm{~L}^{-1}(0.5 \%)$ solution of $10 \mathrm{~N}-22.9 \mathrm{P}-8.3 \mathrm{~K}$ (Plant-Prod, Plant Products, Brampton, Ontario, Canada). When plants reached 15 to $30 \mathrm{~cm}$ in height they were transferred into plastic bags (3 L capacity). After $1 \mathrm{yr}$, emerging seedling shoots were introduced into in vitro culture as previously described for $\mathrm{C} 5$ plantlets.

Certified 'Adesoto 101' plants were obtained as clones of the 'Pollizo de Murcia' plum, originally designated as 'Puebla de Soto-101' - AD by the Pomology Department of the Estación Experimental de Aula Dei, Zaragoza, Spain, and commercially available from Vivero El Tambo (San Vicente de Tagua-Tagua, Santiago, Chile). Potted plants were of approximately $30 \mathrm{~cm}$ in length with $0.5-1.0$ $\mathrm{cm}$ in diameter.

PPV inoculation. PPV infected GF305 peach and $P$. tomentosa plants derived from the work of Reyes et al. (2003) and grown in a quarantine greenhouse were used as inoculum sources for the PPV isolates. In November 2004, 10 'Adesoto 101' plants were inoculated with each of four different isolates (Chile12, Chile112, Chile 114, and Chile116; 40 plants total) by chip budding as described previously (Howard, 1977), inserting two bark segments from infected sources on each plant. Inoculated host populations were kept in a biosafety greenhouse at 25 $\pm 2{ }^{\circ} \mathrm{C}$ and the infection status was routinely checked (see PPV evaluation section below).

Ex vitro micro-grafting. $\mathrm{C} 5$ and $P$. tomentosa in vitro plantlets cultured in $200 \mathrm{~mL}$ vessels up to 3 to $4 \mathrm{~cm}$ in height were selected and $1-2 \mathrm{~cm}$ long shoot tips were cut from these shoots.

Each tip was cut in a "V-shape" at the basal end and kept in water for a brief period until grafting. "Adesoto 101 ' plants previously infected with the different PPV isolates, were selected to provide "stock stems" of equivalent diameter (about $5 \mathrm{~mm}$; candidate lateral shoots) to the in vitro excised "shoot tips". Candidate 'Adesoto 101' shoots were decapitated with a surgical scalpel, and a vertical incision about $5 \mathrm{~mm}$ long was made in the stock stem to insert the in vitro derived shoot tip. The tip was placed into this prepared 'Adesoto 101' shoot 
and oriented so that the cambium exposed by the cut on both sides of the stem was in contact with the freshly cut wedged "V-shaped" base of the tip. Scions were held in place and kept hydrated with several wraps of Parafilm (Pechiney Plastic Packaging, Menasha, Wisconsin, USA). Micro-grafts were covered with a plastic bag, to avoid dehydration. Bags were removed when new leaves were observed on the tips (after $3 \mathrm{wk}$ on average). As a positive control for infection of grafts, non-transgenic PPV susceptible $P$. tomentosa in vitro shoot tips were used. Fifteen each of $\mathrm{C} 5$ and $P$. tomentosa in vitro shoots were micrografted onto 'Adesoto 101' rootstocks infected with each virus isolate. Shoot-tip grafted plants were kept in the greenhouse for the period of study.

PPV evaluation. PPV symptoms appearance was monitored every $3 \mathrm{~d}$, from September to January each season. The presence of the virus either in "Adesoto 101 ' and in micro-grafted materials was confirmed by double-antibody sandwich-indirect enzyme-linked immunosorbent assay (DASI-ELISA), using the PPV Universal ELISA kit (Agritest, Bari, Italy). 'Adesoto 101' hosts and $P$. tomentosa scions were additionally evaluated by reverse transcription-polymerase chain reaction (RTPCR) as described by Rosales et al. (1998), which detects a 220 bp region corresponding to the 3'-non coding region (3'-NCR) of the PPV RNA. Total RNA from leaf samples from 'Adesoto 101' rootstocks and P. tomentosa scions was performed according to Hyman et al. (1998). Evaluations of the grafted populations and 'Adesoto101' hosts were carried out during three consecutive springsummer seasons (September to January 2006-2007, 2007-2008, and 2008-2009). Positive reactions were set up using leaf samples from the previously characterized materials described in Reyes et al. (2003). Corresponding negative controls were made using non-infected certified plants as mentioned in the Plant Materials section. Additionally, control reactions were monitored by routine comparisons with those supplied in the DASI-ELISA kit (Agritest).

Quantitative real-time PCR (qPCR). qPCR PPV evaluations of the rootstocks and micro-grafts were carried out mid-term during the third season of evaluation (the second week in October 2008). Total RNA was isolated from leaf samples of 'Adesoto 101', C5 and P. tomentosa scions using FavorPrep ${ }^{\mathrm{TM}}$ Plant Total RNA extraction kit (Favorgen, Ping-Tung, Taiwan). Remaining DNA was degraded using RQ1 RNase-free DNase (Promega, Madison, Wisconsin, USA) according to the manufacturer's recommendations. A sample of 1 $\mu \mathrm{g}$ of total RNA was reverse transcribed using MMLVRT reverse transcriptase (Promega) and oligo dT primer
(Promega) according to the MMLV manufacturer's recommendations. Gene expression analyses were performed with a StepOne ${ }^{\mathrm{TM}}$ Real Time PCR System (Applied Biosystems, Foster City, California, USA), using SYBR ${ }^{\circledR}$ Green as fluorescent dye. Viral mRNA was quantified using the specific primers for the cylindrical inclusion $(\mathrm{CI})$ and coat protein $(\mathrm{CP})$ viral proteins. Primers [CI_333 F]: 5'CAGGCCGCTAGCTGAGAATG3' and [CI_406 R]: 5'GCATGCGCAGTGTAGGATTG3', that amplify a fragment of $74 \mathrm{bps}$ from the CI gene and [CP_367 F]: 5'CCTGCACAGGTTGACTTGTCA3' and [CP_441 R]: 5' TCGCTTAACTCCTTCATACCAAGTT3', that amplify a fragment of 75 bps from the CP gene, both based on the PPV sequence Acc. Number NC 001445. qPCRs were performed using $100 \mathrm{ng}$ of cDNA prepared as described, using $4 \rho \mathrm{mol}$ of each primer and Fast SYBR ${ }^{\circledR}$ Green Master Mix (Applied Biosystems) according to manufacturer's indications.

An initial template denaturation and enzyme activation step at $95{ }^{\circ} \mathrm{C}$ for $10 \mathrm{~min}$ was followed by 40 cycles of the two-step amplification: template denaturation at $95{ }^{\circ} \mathrm{C}$ for $3 \mathrm{~s}$ and primer annealing and extension at 60 ${ }^{\circ} \mathrm{C}$ for $30 \mathrm{~s}$. Fluorescence data were collected through amplification after the second step at each cycle. Melting curve analyses were performed by heating the template at $95{ }^{\circ} \mathrm{C}$ for $15 \mathrm{~s}$, cooling to $60{ }^{\circ} \mathrm{C}$ for $60 \mathrm{~s}$ and finally by increasing the temperature up to $95^{\circ} \mathrm{C}$ at a rate of 0.3 ${ }^{\circ} \mathrm{C} \mathrm{s}^{-1}$, with continuous fluorescence acquisition. All data analysis was performed with StepOne ${ }^{\mathrm{TM}}$ Software v2.0 (Applied Biosystems). Absolute quantifications were derived from gene-specific standard curves built using different RT-PCR product concentrations determined spectrophotometrically. The melting curves were checked for single peaks, and the size of the amplification product was confirmed by acrylamide gel electrophoresis and silver staining. Three qPCR determinations were performed for each sample and the expression values were normalized using the $18 S$ ribosomal gene, indicated as Expression in arbitrary units (AU), which was amplified using primers [Prunus18S_489 F]: 5' CGCGGTTGGCATAAATGC 3' and [Prunus18S_551 R] 5' GTTTCGCAACCACCGATTGT 3' that amplify a fragment of $63 \mathrm{bp}$. All primers were designed using Primer Express 3.0 (Applied Biosystems). qPCR data were subjected to ANOVA using the $F$-test and contrast statement in order to discriminate statistical differences at the 5\% level of significance using Statgraphics Plus 5.1 (Manugistics, Rockville, Maryland, USA).

\section{RESULTS}

'Adesoto 101' greenhouse grown plants infected with PPV in late spring (November 2004) showed symptoms 
in the next growing season (October 2005). ELISA and RT-PCR detections revealed that the overall efficiency of infection was $98 \%$. All inoculated hosts were positive after inoculation with the isolates Chile12, Chile114, or Chile116; whereas nine out of the 10 inoculated plants become infected after inoculation with the isolate Chile112. All these isolates caused leaf deformation, yellow spotting, chlorosis, and chlorotic veins in the foliar lamina (Figure 1 A-D). Occasionally, the isolate Chile116 produced well-defined chlorotic rings in the lamina of older leaves (Figure 1E) of these hosts. The 39 infected 'Adesoto 101' plants were used as rootstocks for micrografting with C5 and P. tomentosa shoots. A total of 60 scions ( 27 of C5 and 33 of $P$. tomentosa) were successfully micro-grafted on branches of the infected 'Adesoto 101' hosts (Table 1).

Micro-grafting was initiated in the early spring (October 2006). P. tomentosa grafts in the greenhouse showed PPV symptoms as soon as 15 to $20 \mathrm{~d}$ after grafting (November 2006) and symptoms were observed until the end of the growing season (March 2007). Chlorotic banding along the midrib and the secondary veins and
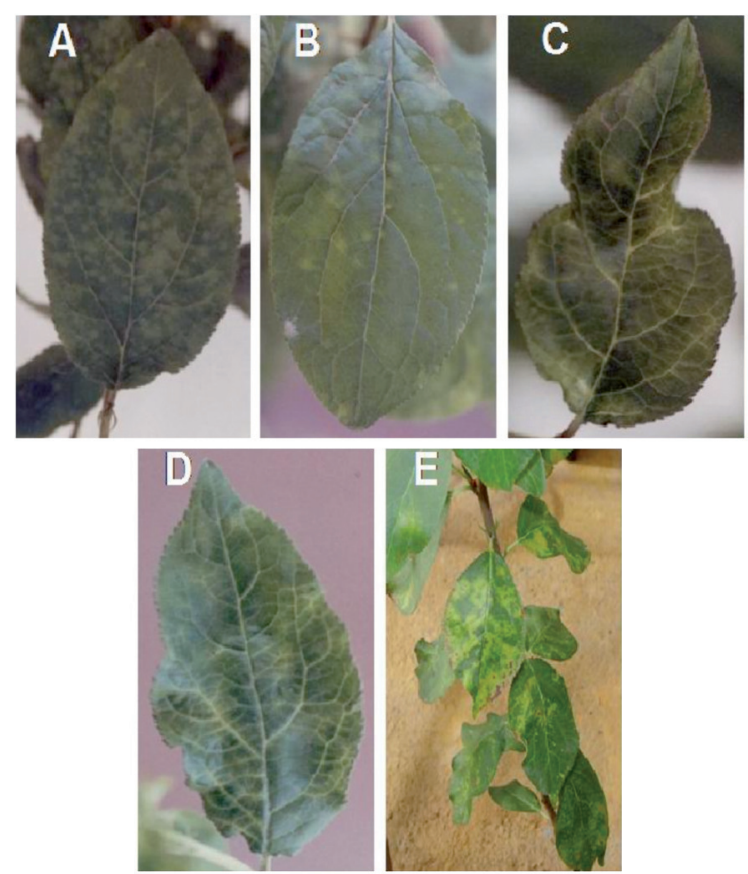

Leaf deformation, yellow spotting, chlorosis, and chlorotic veins in the foliar lamina of infected plants with the four isolates (Chile12, Chile112, Chile114, and Chile116) (A-D). In the specific case of Chile116 isolate, well-defined chlorotic rings were seen in the lamina of older leaves (E). Plants were infected by chip budding in November 2004 and symptoms were scored by the first time in October 2005.

Figure 1. Symptomatology of 'Adesoto101' (Prunus insititia) plants infected with four different Chilean Plum pox virus isolates.

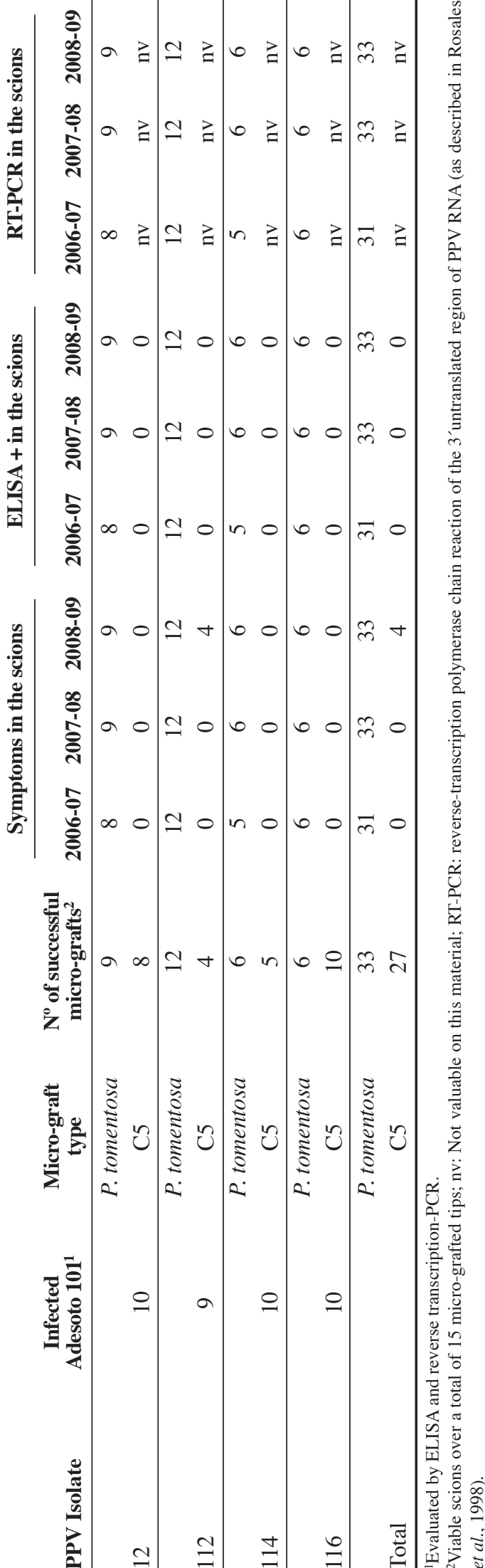


chlorotic and necrotic spots were observed (Figure 2C). During the second growing season (October 2007-January 2008), the same symptoms appeared at the beginning of spring (Figure 2F). Symptoms were consistently correlated with positive ELISAs and RT-PCRs carried out on leaf material from those P. tomentosa shoots (Table 1). For C5 scions grafted on 'Adesoto 101' rootstocks (Figure 2A), no symptoms were observed at any of the C5 materials during the first two seasons in the study (Figure 2D and $2 \mathrm{G}$ ) and the virus was not detected by ELISA (Table 1). At the third season of analysis, whereas $P$. tomentosa scions
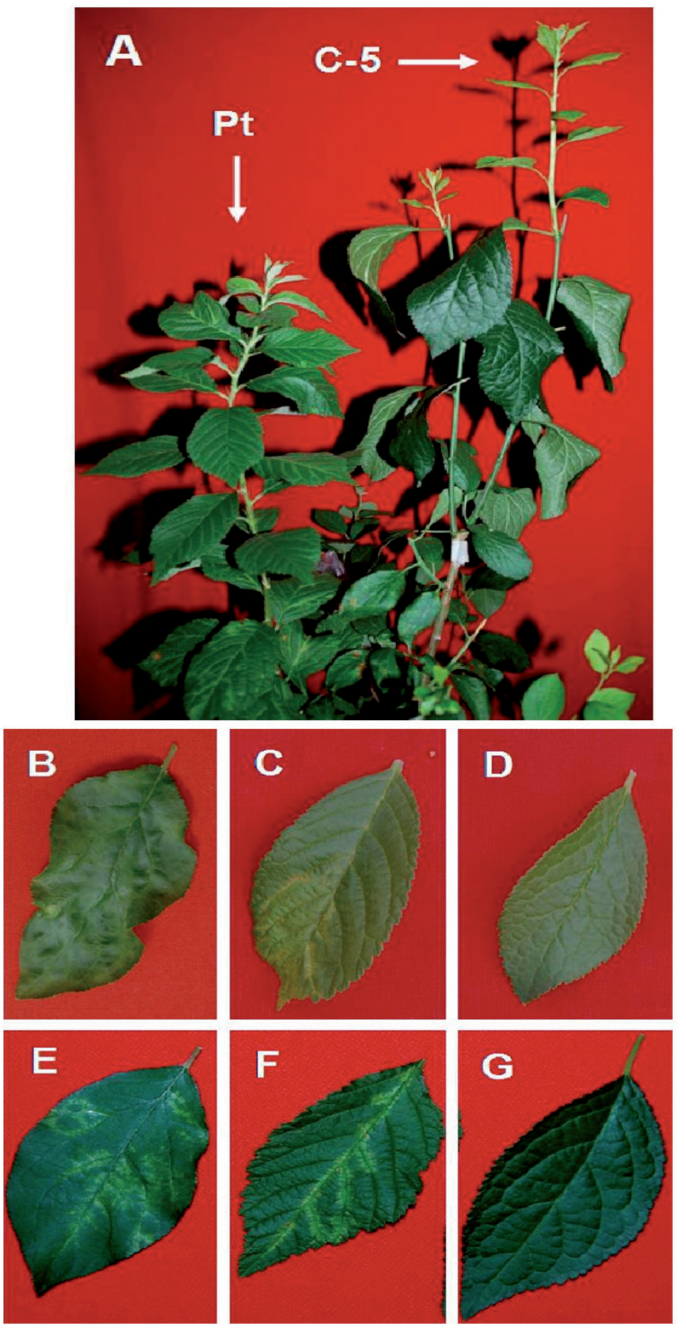

'Adesoto 101' plants positively infected by chip budding with four different Chilean Plum pox virus isolates were micrografted with Prunus tomentosa (Pt) and C5 (C-5) tips (A). Details of symptomatologies on foliar laminas are shown for 'Adesoto 101' (B, E), P. tomentosa $(\mathrm{C}, \mathrm{F})$ and $\mathrm{C} 5(\mathrm{D}, \mathrm{G})$ leaves during two different seasons (2006-2007: B, C, D; and 2007-2008: E, F, G).

Figure 2. Plum pox virus (PPV) symptomatology on Prunus tomentosa and C5 shoots micro-grafted on 'Adesoto101' ( $P$. insititia) PPV infected hosts during the first $2 \mathrm{yr}$ of analyses.
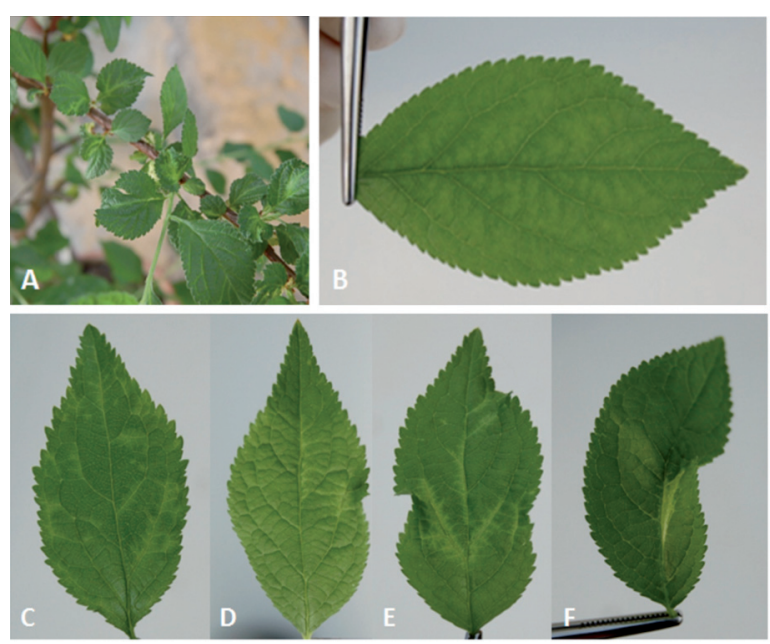

'Adesoto 101 ' plants positively infected by chip budding with four different Chilean Plum pox virus (PPV) isolates were micro-grafted with Prunus tomentosa and C5 scions. At the third year of analyses P. tomentosa scions exhibited a marked general symptomatology of PPV disease (generically illustrated by A) which was completely absent in three of the C5 micro-grafted populations (generically illustrated by B). C5 scions on Chile112 infected 'Adesoto 101' showed a slight leaf symptomatology with chlorotic veins $(\mathrm{C})$, and leaf deformation at different levels (D-F) in the basal zone of the graft union.

Figure 3. Plum pox virus (PPV) symptomatology at the third season of analysis on Prunus tomentosa and C5 scions micro-grafted onto four different PPV infected 'Adesoto101' ( $P$. insititia) populations with four different virus isolates.

showed marked infection symptoms (Figure 3A), absence of symptoms was again the common pattern in all of the C5 scions grafted onto Chile12-, Chile114-, or Chile116infected Adesoto hosts (Figure 3B), which correlated with negative ELISA results. Conversely, four C5 scions grafted on the Chile112 challenged population, showed chlorotic veins (Figure 3C) and different degrees of leaf deformation (Figure 3D-F); these symptoms were seen mostly on the basal leaves of the C5 scions. However, ELISA screenings on these symptomatic C5 scions were negative.

Considering this differential behavior obtained at the third season of evaluations, a detailed molecular analysis of the grafted populations was carried out. Comparative detections using absolute qPCRs, were designed in order to detect the presence of two PPV sequences: $\mathrm{CI}$ and CP. $\mathrm{C} 5$ plum was generated by incorporation of a full length version of the PPV-CP gene into its genome; consequently, detection of CP mRNAs in the scions should detect gene activities of both plant transgene and virus. On the other hand, CI mRNA detection in the scions should exclusively represent the viral content in the plant. As expected, both viral mRNAs were detected in the PPV-infected Adesoto 101 rootstocks, regardless the isolate used in 


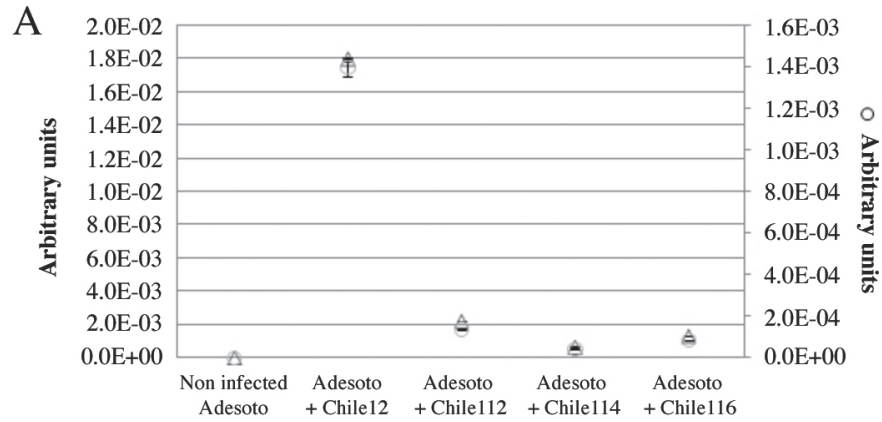

B

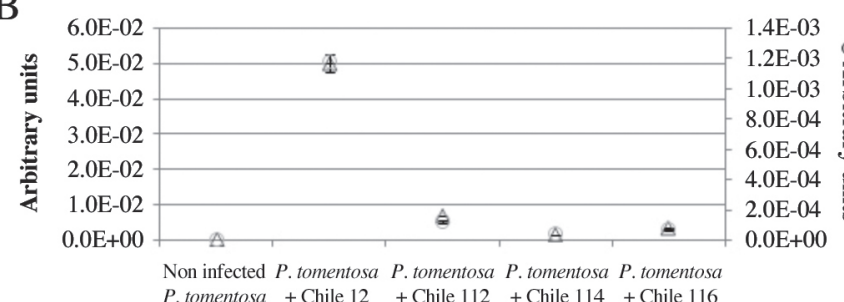

$\mathrm{C}$

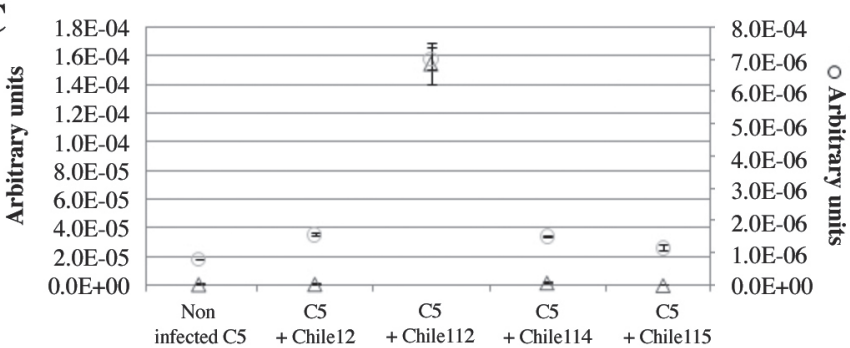

Levels of infections in the 'Adesoto 101' hosts are described as arbitrary units of CP and CI mRNAs in both healthy (non infected) and PPV inoculated plants with four different Chilean PPV isolates (Chile12, Chile112, Chile114, and Chile 116) (A). The same mRNA levels were determined in PPV-sensitive P. tomentosa control (B) and in PPV-resistant C5 plum (C) tips micro-grafted on these Adesoto 101 populations. Determinations were normalized against 18 S ribosomal gene and viral mRNAs are indicated as expression in arbitrary units. Values correspond to average arbitrary units from three different determinations and gene specific vertical scales have been applied. Bars indicate standard deviation at $p \leq 0.05$.

Figure 4. Quantitative polymerase chain reaction (qPCR) determinations of Plum pox virus (PPV) coat protein (CP, circles) and cylindrical inclusion (CI, triangles) mRNAs in leaf material from 'Adesoto 101' plants micro-grafted with Prunus tomentosa and C5 tips.

the inoculation (Figure 4A). While no viral mRNAs were detected in the $P$. tomentosa scions micro-grafted onto non-infected Adesoto rootstocks, both mRNAs were detected in the P. tomentosa scions of the plants having PPV-inoculated Adesoto as a rootstock (Figure 4B). In case of C5 scions, as expected based on Scorza et al. (1994) CP mRNA levels were found in very low amounts either in tips grafted onto non-inoculated or in tips grafted onto inoculated (Figure 4C) Adesoto rootstocks. CI was not detected on the C5 shoots grafted onto noninoculated Adesoto rootstocks or onto those inoculated rootstocks with the PPV isolates Chile12, Chile114 and Chile116, which had not produced symptoms in the C5 grafted shoots (Figure 4C). However, a low level of CI mRNA was detected in C5 micro-grafts established onto the population of Adesoto 101 rootstocks infected with the isolate Chile112 (Figure 4C) which had shown mild symptoms on a few leaves near the graft union (Figure 3C-F).

\section{DISCUSSION}

Searching for reliable and quick screening systems for the evaluation to PPV resistance has been claimed as a final objective since more than $10 \mathrm{yr}$. Quarantine rules force researchers to evaluate the resistance applying methods that show important limitations resulting from the management of plants in the controlled conditions, grown in pots with artificial cycles of growth in the greenhouse and cold chamber, alternately (Rubio et al., 2009). In this work, micro-grafts facilitated the study of resistance of 
the transgenic plum clone C5 to PPV, a case in which GMO and pathogen containment requirements severely limit working options. The artificial transmission of PPV in Prunus spp. is sometimes problematic due to the low concentration of the virus and its uneven distribution throughout the plant (Bodin-Ferri et al., 2002). Because of this, it has been suggested that inoculations and handling of hosts should be carried out in spring and using branches of different parts of the tree as inoculum (Gentit, 2006), and that the expected time to correctly evaluate the reaction of tested clones is at least of two vegetative periods (Lansac et al., 1998). Micro-grafts, in vitro as well as ex vitro, have been used for research issues such as studying the rootstock-variety incompatibility (Gebhardt and Goldbach, 1988), establishing transgenic lines (Lane et al., 2003), detection of phytoplasmas and virus (Pathirana and McKenzie, 2005) and evaluation of tolerant clones (Lansac et al., 1998). Researchers involved in development of PPV-resistant cultivars have recommended bud grafting of the materials to be evaluated on PPV-infected Prunus persica GF-305 plants (Rubio et al., 2009). With that method, the symptoms can only be observed at least 6 wk after treatments, and a cold shock is required. Contrastingly, micro-grafting of $P$. tomentosa controls on 'Adesoto 101' allowed symptoms observation just 2 or 3 wk after technical processing and without requirement for cold treatment. In that way, the ex vitro micro-grafting approach used here may provide a quick and effective alternative for evaluation of resistance to PPV.

Our results confirmed the high level of C5 plum resistance to PPV and extend this to three of four Chilean isolates evaluated. During the first $2 \mathrm{yr}$ of analysis, a resistance pattern was seen in all the micrografted individuals with these different D isolates. At the third season of evaluations, our studies described the observation of mild symptoms in some basal leaves close to the grafting zone with one specific isolate (Chile112). The appearance of symptoms in these individuals was correlated with qPCR analysis for the CI viral gene (Figures 3 and 4). The phenomenon was observed only on C5 shoots exposed to the Chile112 isolate which is closely related to isolate 12 (Reyes et al., 2003) on the basis of aminoacid and nucleotide similarities in the $\mathrm{CP}$ gene. However, no virus was detected in C5 shoots exposed to isolate 12. While the basis for this phenomenon is unclear it is not unique. In previous studies, carried out either in greenhouse or field, it has been shown that while most C5 plants grafted onto PPV-susceptible rootstocks previously inoculated by chip budding or with aphids, were asymptomatic and the virus was not detected by ELISA or RT-PCR (Ravelonandro et al., 2002) a small proportion of graft inoculated C5 trees and those grafted onto infected rootstocks may harbor a low level infection, generally limited to areas adjacent to the graft union (Hily et al., 2004; Malinowski et al., 2006). Recently, Kundu et al. (2008) reported under greenhouse conditions a single C5 scion-that displayed mild sharka-like symptoms and positive RT-PCR detection on leaves adjacent to the inoculum graft union. The positive reaction to PPV was found to be transient and associated with a temporary loss or inhibition of the activity of the long class (25-26 nt) siRNA. It was speculated that this phenomenon may have been related to environmental factors.

The proposed mechanism of resistance in $\mathrm{C} 5$, posttranscriptional gene silencing (PTGS) (Scorza et al., 2009), has been specifically confirmed by detection of small interfering RNAs (siRNA) (Kundu et al., 2008). It has been indicated that PTGS in C5 may be due to the presence of an inverted repeat of the $\mathrm{CP}$ gene sequence in the C5 genome (Scorza et al., 2009). The presence of low amounts of CP mRNA in C5 scions grafted onto uninfected plants (Figure 4C) and the low levels of CP mRNAs in the asymptomatic C5 scions grafted onto infected plants are consistent with the hypothesis of an observed resistance to Chilean PPV isolates also being mediated by post-transcriptional CP gene silencing. According to this idea, Western blot evaluations carried out on all of the C5 scions, showed no CP occurring in these tissues (not shown). In the same line, the homology-dependent resistance accepted in PTGS could also explain in some degree the slight symptomatology observed in the C5 shoots grafted onto 'Adesoto 101' plants infected with Chile112; neighbor-joining analyses of the PPV sequences in C5 (Accession $\mathrm{N}^{\circ} \mathrm{X} 16415$ ) (Teycheney et al., 1989) and the CP gene sequences from the four isolates [Accession $\mathrm{N}^{\circ}$ AF440741 (Chile112), AF4400742 (Chile114), AF440743 (Chile116), and AF440744 (Chile12); Reyes et al., 2003], grouped Chile114 and Chile116 in a common branch to the C5 (Teycheney's) sequences, and these separated from Chile12 and Chile112, which clustered each one in a different side chain (not shown).

C5 is the first transgenic woody fruit-tree highly resistant to PPV with good agronomic characteristics whose resistance phenotype has been sexually transmitted into two commercially important plum cultivars (Ravelonandro et al., 2002). Recently, it has been deregulated by the US Department of Agriculture (USDA) and Food and Drug Administration (FDA), and may be used commercial purposes in the near future. These facts lead us to important challenges referred to local adoptions of C5 or C5-derived clones, and require good technical approaches for evaluations of these materials under the same local conditions. The characterization of C5's 
behavior in response to challenge with Chilean isolates is a necessary first step for local regulatory assessment. The current results demonstrate the stability of this resistance in C5 under our trial conditions and with infection with Chilean isolates of PPV. Before an adoption of $\mathrm{C} 5$ as a viable technology, field trials and evaluations during multiple seasons, including natural conditions of infection would be necessary.

\section{CONCLUSIONS}

In the present work we designed an experimental approach for the evaluation of C5 transgenic plum under confined conditions. Micro-grafting procedures based on the use of susceptible 'Adesoto 101' individuals as rootstocks, allowed the generation of stable PPV infected populations able to transmit the virus into their corresponding scions (control P. tomentosa and C5), and at the same time, acting as good indicator hosts depicting marked symptoms at appropriate rates after chip-budding infections.

Disease results on C5 scions revealed an important resistance degree during the first $2 \mathrm{yr}$ of evaluations (characterized by symptoms absence, undetectable amount of viral antigens and low viral mRNA levels). Resistance resulted overcome at the third year of evaluations by one of these $\mathrm{D}$ Chilean isolates, generating mild symptoms in C5 leaves close to the grafting area and detectable viral mRNA levels in the scion. According to this, PTGS kinetics along the scion and the effect of environmental factors on this plant-virus interaction can be of main interest for these studies, stressing a necessity for carry out middle-to-long term assays and preferably involving field testing, upon natural disease (and vector) pressure.

To our knowledge, this is the first report on the evaluation of a transgenic fruit tree in Chile including a simultaneous analysis of a quarantine disease such as Plum pox virus. In that line, both technical approaches and biological results can be considered of considerable importance for future similar works in this area.

\section{ACKNOWLEDGEMENTS}

We thank to Dr. Michel Ravelonandro (Institut National de la Recherche Agronomique, INRA-Bordeaux), and Nicola Fiore (Universidad de Chile), for their critical review of this manuscript and the collaboration in the handling of PPV isolates, respectively. This work was funded by grants FDI-CORFO-Chile 02LE2-0005 and Biotecnología Frutícola S.A./Biofrutales (Programa Bicentenario de Ciencia y Tecnología, PBCT-Chile).

\section{RESUMEN}

Evaluación de la resistencia de ciruelo transgénico C5 (Prunus domestica L.) contra cuatro aislamientos chilenos del Virus pox del ciruelo a través de microinjertos. El ciruelo (Prunus domestica L.) transgénico $\mathrm{C} 5$, que posee inserto el gen de la proteína de cubierta (CP) del Plum pox virus (PPV), es un ejemplo excepcional del uso de ingeniería genética para el mejoramiento de Prunus spp. Pruebas de campo realizadas en Polonia, Rumania y España han demostrado su resistencia a distintos aislamientos de PPV cepas D y M. En Chile, dadas las regulaciones cuarentenarias para PPV y para plantas genéticamente modificadas, los análisis de resistencia de C5 deben ser ejecutados bajo condiciones de confinamiento. Para realizar estas pruebas, se multiplicaron in vitro brotes de C5 y se microinjertaron en cuatro grupos de 'Adesoto 101' (Prunus insititia L.) previamente infectados con cuatro aislamientos de PPV-D chilenos ya caracterizados. Todos los ensayos se realizaron bajo condiciones controladas en invernadero de bioseguridad. Durante tres temporadas se analizó sintomatología, presencia de virus y niveles de mARN viral para los genes de la proteína de inclusión cilíndrica (CI) y CP. Durante los primeros 2 años se encontró una resistencia completa a todos los aislamientos en todos los injertos. $\mathrm{Al}$ tercer año, cuatro de 10 injertos $\mathrm{C} 5$ mostraron síntomas leves en hojas cercanas al sitio de injertación y un nivel bajo, pero detectable, de mARN de CI. Estos resultados avalan la utilidad de la microinjertación en $P$. insititia para estudios de resistencia a PPV, especialmente en un recinto cuarentenario, mientras que los niveles de resistencia mostrados por C5 luego de 3 años indican la necesidad de evaluaciones prolongadas y preferentemente en campo .

Palabras clave: C5, Plum pox virus, aislamientos chilenos, Prunus domestica, Prunus insititia, microinjertación.

\section{LITERATURE CITED}

Bodin-Ferri, M., E. Costes, J.B. Quiot, and F. Dosba. 2002. Systemic spread of Plum pox virus (PPV) in mariana plum GF8-1 in relation to shoot growth. Plant Pathology 51:142-148.

Gebhardt, K., and H. Goldbach. 1988. Establishment, graft union characteristics and growth of Prunus micrograft. Physiologia Plantarum 72:153-159.

Gentit, P. 2006. Detection of Plum pox virus: Biological methods. Bulletin OEPP/EPPO Bulletin 36:251-253. 
Herrera, G., y M. Madariaga. 2003. Diseminación natural del virus causante de la enfermedad de Sharka (Plum pox virus, PPV) en tres temporadas en un huerto de damasco. Agricultura Técnica (Chile) 63:202-206.

Hily, J., R. Scorza, T. Malinowski, B. Zawadzka, and M. Ravelonandro. 2004. Stability of gene silencingbased resistance to Plum pox virus in transgenic plum (Prunus domestica L.) under field conditions. Transgenic Research 13:427-436.

Hyman, L., I. Toth, and M. Pérombelon. 1998. Isolation and identification p. 60-65. In Pérombelon, M.C.M., and J.M. Van Der Wolf (eds.) Methods for the detection and quantification of Erwinia carotovora subsp. atroseptica on potatoes. Laboratory Manual. Scottish Crop Research Institute, Invergowrie, Scotland, UK.

Howard, B. 1977. Chip budding fruit and ornamental trees. Proceedings International Plant Propagators Society 27:357-364.

Karayiannis, I. 2006. Progress in apricot breeding for resistance to sharka disease (Plum pox virus, PPV) in Greece. Acta Horticulturae 717:93-96.

Kundu, J.K., P. Briard, J. Hily, M. Ravelonandro, and R. Scorza. 2008. Role of the 25-26 nt siRNA in the resistance of transgenic Prunus domestica graft inoculated with Plum pox virus. Virus Genes 36:215220.

Lane, W., B. Bhagwat, J. Armstrong, and S. Wahlgren. 2003. Apple micrografting protocol to stablish transgenic clones ob field ready roostock. HortTechnology 13:641-646.

Lansac, M., L. Chalak, B. Cardona, A. Sorbier, M. BodinFerri, F. Dosba, et al. 1998. In vitro inoculation of Prunus species with Plum pox potyvirus. Acta Horticulturae 472:455-459.

Llácer, G., and G.M. Cambra. 2006. Hosts and symptoms of Plum pox virus: Fruiting Prunus species. Bulletin OEPP/EPPO Bulletin 36:219-21.

Malinowski, T., M. Cambra, N. Capote, B. Zawadzka, M. Gorris, R. Scorza, and M. Ravelonandro. 2006. Field trials of plum clones transformed with the Plum pox virus coat protein (PPV-CP) gene. Plant Disease 90:1012-1018.

Moreno, M., M. Tacabuena, and R. Cambra. 1995. Adesoto 101, a plum rootstock for peach and other stone fruit. HortScience 30:1314-1315.

Murashige, T., and F. Skoog.1962. A revised medium for rapid growth and bioassays with tobacco tissue cultures. Physiologia Plantarum 15:473-497.
Pathirana, R., and J. McKenzie. 2005. Early detection of Grapevine leafroll virus in Vitis vinifera using in vitro micrografting. Plant Cell Tissue and Organ Culture 81:11-19.

Polák, J., J. Pívalová, M. Kundu, M. Jokes, R. Scorza, and M. Ravelonandro. 2008. Behaviour of transgenic Plum pox virus-resistant Prunus domestica L. Clone C5 grown in the open field under a high and permanent infection pressure of the PPV-rec strain. Journal of Plant Pathology 90 (1, Supplement), S1.33-S1.36.

Ravelonandro, M., P. Briard, M. Monsion, and R. Scorza. 2002. Stable transfer of the Plum pox virus (PPV) capsid transgene to seedlings of two French cultivars 'prunier d'ente 303' and 'quetsche 2906', and preliminary results of PPV challenge assays. Acta Horticulturae 577:91-96.

Reyes, F., N. Fiore, M. Reyes, P. Sepúlveda, V. Paredes, and H. Prieto. 2003. Biological behaviour and partial molecular characterization of six Chilean isolates of Plum pox virus. Plant Disease 87:15-20.

Rosales, M., P. Hinrichsen, and G. Herrera. 1998. Molecular characterization of Plum pox virus isolated from apricots, plums and peaches in Chile. Acta Horticulturae 427:401-405.

Rubio, M., A. García-Ibarra, P. Martínez-Gómez, and F. Dicenta. 2009. Analysis of the main factors involved in the evaluation of Prunus resistance to Plum pox virus (Sharka) in controlled greenhouse conditions. Scientia Horticulturae 123:46-50.

Scorza, R., L. Georgi, A. Callahan, C. Petri, J. Hily, C. Dardick, et al. 2009. The hairpin structure of the Plum pox virus coat protein gene in HoneySweet C5 plum is responsible for PPV resistance. 21st International Conference on Virus and other Graft Transmissible Diseases of Fruit Crops. 5-10 July. Julius KühnInstitut, Agroscience Ltd. and German Phytomedical Society (DPG), Neustadt, Germany.

Scorza, R., M. Ravelonandro, A. Callahan, J. Cordts, M. Fuchs, J. Dunez, and D. Gonsalves. 1994. Transgenic plums (Prunus domestica L.) express the Plum pox virus coat protein gene. Plant Cell Reports 14:18-22.

Teycheney, P.Y., G. Tavert, R. Delbos, M. Ravelonandro, and J. Dunez. 1989. The complete nucleotide sequence of Plum pox virus RNA (strain D). Nucleic Acids Research 17:10115-10116. 